\title{
Letter to Editor: Lessons Learned From Trauma Injuries in Arbaeen 2019 in Ilam Province, Iran
}

\author{
Aliashraf Mozafari ${ }^{1}$ Q Elham Shafiei $^{1}$, Yousef Jamshibeigi², Ali Sahebi ${ }^{1^{*}}$ \\ 1. Clinical Research Development Unit, Shahid Mostafa Khomeini Hospital, Ilam University of Medical Sciences, Ilam, Iran. \\ 2. Department of Anesthesia, School of Paramedical, Ilam University of Medical Sciences, Ilam, Iran.
}

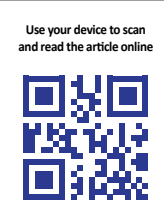

Citation: Mozafari A, Shafiei E, Jamshibeigi Y, Sahebi. Lessons Learned From Trauma Injuries in Arbaeen 2019 in Ilam Province, Iran. International Journal of Medical Toxicology and Forensic Medicine. 2020; 10(2):28614. https://doi.org/10.32598/ ijmtfm.v10i2.28614

https://doi.org/10.32598/ijmtfm.v10i2.28614

rbaeen is the largest peaceful religious gatherings on Earth. In this event, milA lions of people go to the holy city of Karbala in Iraq. Annually, about 20 million pilgrims attend Arbaeen ceremony, including about three million foreigners, that most of whom are Iranians [1-3]. Ilam province is located near Iran's western border with Iraq. Every year, many Iranian pilgrims enter Iraq through Ilam borders for the Arbaeen ceremony, which lasts two weeks before and after Arbaeen day. Pilgrims after the religious rituals enter to their home [4].

On Arbaeen 2019, about 144000 pilgrims were referred to Ilam province hospitals and health centers, and 1571 of these patients had trauma injuries. In January 2017, 105 pilgrims were admitted to Ilam academic hospitals and 56 of these pilgrims to the surgical and intensive care unit wards [5]. The survey of these studies shows the number of referrals to Ilam hospitals between 2017 and 2019 has been an increasing trend. Although in large gatherings, the risk of infectious diseases is high compared with other diseases, trauma injuries must also be considered. Lessons learned from trauma injuries in the Arbaeen ceremony were as follows:
- Identify road accident areas and improve road quality standards, one of the issues that may be necessary to reducing the number of fatalities caused by road accidents.

- Despite the availability of public vehicles to transport pilgrims to Arbaeen, some pilgrims use personal vehicles, and they have to travel long distances to attend the ceremony. When they return home, they are tired and drowsy. Therefore, the probability of accidents is high, and they should be advised to avoid driving when they are exhausted.

- Advise pilgrims to use public vehicles to attend Arbaeen.

- Pilgrims that use personal vehicles from other parts Iran country to participate in Arbaeen ceremony are unfamiliar with the roads in these areas. Accordingly, drivers must be informed about the accident-prone areas during the day and night.

- To prevent road accidents, the road infrastructure must be improved as the number of pilgrims to the Arbaeen ceremony increased annually.

- Using a railway transportation system can play an essential role in reducing traffic injuries in large gatherings because using this transportation system can move a large number of people, and it is time-consuming. It

* Corresponding Author:

Ali Sahebi, PhD.

Address: Clinical Research Development Unit, Shahid Mostafa Khomeini Hospital, Ilam University of Medical Sciences, Ilam, Iran.

Tel: +98 (84) 33338228

E-mail: ali.sahebi.phd@gmail.com 
also reduces dependency on buses and prevents road accidents [6].

\section{Ethical Considerations}

\section{Compliance with ethical guidelines}

This letter to the editor did not require a consent form and ethical code.

Funding

This research did not receive any specific grant from funding agencies in the public, commercial, or not-forprofit sectors.

\section{Author's contributions}

All authors contributed in preparing this article.

\section{Conflict of interest}

The authors declared no conflict of interest.

\section{Acknowledgements}

The authors thank and appreciate the Clinical Research Development Unit of Shahid Mostafa Khomeini Hospital in Ilam, Iran.
[5] Nazari A, Shohani M, Tavan H. Comparative study of contagious diseases and their related risk factors in the children and adults pilgrims referred to educational and treatment centers in Ilam on the day of Arbaeen in 2017. J Compr Ped. 2019; 10(4):e85771. [DOI:10.5812/compreped.85771]

[6] Kasthala S, Lakra HS. Disaster preparedness for mass religious gatherings in India-learning from case studies. Second World Congress on Disaster Management; 2015 Nov 20; New Dehli: India.

\section{Reference}

[1] Taher A, Abo-ghniem TN, Albujeer AN, Almahafdha A, Khoshnevisan MH. Oral hygiene and mass gathering of Iraqi and non-Iraqi visitors in Arbaeen; A random sample survey for 3500 visitors. Res Rev J Dent Sci. 2017; 5(1):92-5. http:// www.rroij.com/open-access/oral-hygiene-and-mass-gathering-of-iraqi-and-noniraqi-visitors-in-arbaeen-a-random-sample-survey-for-3500-visitor-.pdf

[2] Fouladi F, Mahvi A, Hosseini S, Khazaeic M. Fluoride concentration in bottled drinking water available in Najaf and Karbala, Iraq. Fluoride. 2014; 47(3):249-52. http:/ / www.fluorideresearch.org/473/files/FJ2014_v47_n3_p249-252_sfs.pdf

[3] Rasouli HR, Ahmadpour F, Khoshmohabat H, Farajzadeh MA. Health concepts regarding Arbaeen's foot-pilgrimage. Traume Mon. 2019; 24(2):e82177. [DOI:10.5812/traumamon.82177]

[4] Nazari A, Noori G, Mohammadyari E, Taebi G, Tavan H. Survey of infectious and non-infectious diseases and the survival of pilgrims at health centers of Ilam on the day of Arbaeen in 2016. Iran Red Crescent Med J. 2018; 20(S1):e14538. [DOI:10.5812/ircmj.14538] 